RESEARCH REPORT

\title{
Variation of health status among people living on boats in Hue, Vietnam
}

\section{Nguyen Khac Luong Quang, Takehito Takano, Keiko Nakamura, Masafumi Watanabe, Tomoko Inose, Yoshiharu Fukuda, Kaoruko Seino}

J Epidemiol Community Health 2005;59:941-947. doi: 10.1136/jech.2005.034728

\author{
See end of article for \\ authors' affiliations \\ avts affiations \\ Correspondence to: \\ Professor T Takano, Health \\ Promotion/International \\ Health, Graduate School \\ of Tokyo Medical and \\ Dental University, Yushima \\ 1-5-45, Bunkyo, Tokyo \\ 113-8519, Japan; takano. \\ hlth@tmd.ac.jp \\ Accepted for publication \\ 16 May 2005
}

\begin{abstract}
Objectives: To examine patterns of disease and injury in people living on boats in Hue City, Vietnam, and their relations to socioeconomic conditions, sanitary practices, disease prevention proficiency, and people's preference to continued living on boats.

Methods: The subjects were 3737 people aged 5 years and over living on boats in Hue City, Vietnam. Diseases and injuries were diagnosed according to ICD-10. The associations between disease/injury and socioeconomic conditions, sanitary practices, disease prevention proficiency, and preference to continued living on boats were analysed by logistic regression.

Main results: The prevalence rates of certain infectious and parasitic diseases, diseases of the respiratory system, diseases of the skin and subcutaneous tissue, diseases of the digestive system, and injuries were $85.3 \%, 78.0 \%, 51.2 \%, 15.4 \%$, and $13.2 \%$, respectively. Various associations were seen between diseases/injuries and socioeconomic conditions. Patterns of disease were strongly influenced by sanitary practices. Better disease prevention proficiency was significantly related to lower prevalence of the first three categories of diseases/injuries regardless of sex, age, or socioeconomic status $(p<0.05, p<0.001$, $p<0.001$, respectively). Diseases were more prevalent among people who preferred not to continue living on boats.

Conclusions: This large scale comprehensive field study illustrated major diseases and injuries among people living on boats. Variations in health status showed a web-like relation of socioeconomic conditions, sanitary practices, disease prevention proficiency, and preference to continued living on boats. Measures to develop disease prevention proficiency reduce the risk of disease and injury.
\end{abstract}

To consider the health of people under fragile living conditions, solid evidence on variation in health and disease in this population is required. However, systematic boat household studies have not been carried out to quantify disease and injury in Hue City. Such quantitative analyses and examinations of factors related to their health would provide evidence to facilitate the planning for health developments. In this study, we performed a household survey focusing on a wide range of variables, including demographic, socioeconomic, sanitary practices, disease prevention proficiency, and health status.

The objectives of this study were to determine disease and injury patterns of people living on boats along the Huong River in Hue City and their relations with socioeconomic conditions, sanitary practices, disease prevention proficiency, and people's preference regarding continued living on boats.

\section{METHODS}

\section{Study area and subjects}

The study area consisted of six quarters of Hue City-Phu Hau, Phu Hiep, Vy Da, Phuong Duc, Kim Long, and Phu Cat - which included 941 households living on boats according to the household registration records. The subjects of health examination were people aged 5 years and over from boat households.

\section{Procedures}

Ten interview teams were assigned to visit boat households and conducted interviews and health examinations from 4 August to 19 September 2003. A team of three people-one medical doctor, one nurse, and one civil servant-met the heads of household and carried out face to face interviews influencing the health of a particular population will provide a basis for measures to improve the health of the population. 
using structured questionnaire forms. The medical doctor and nurse examined health conditions of household members aged 5 years and over. The interview team members participated in a two day training workshop in advance, to obtain appropriate knowledge and skills for the interview and health examination as well as to understand the objectives and protocol of the study.

Permission to implement the study was obtained from Hue People's Committee by consideration of ethical appropriateness. Informed consent from the heads of households and household members were obtained. The heads of the quarters and key people in the community were informed of the purposes and expected outcomes as well as general protocol of the study, in advance.

\section{Questionnaire survey}

Structured questionnaire forms were prepared in Vietnamese, and were pre-tested in the field to ensure that all questions could be understood clearly. The interview method was standardised through practice visits to boat households by the interview teams. The following items were assessed.

\section{Demographic and socioeconomic conditions}

Age, sex, family size, education level, income, and occupation. Family size was categorised as non-crowded ( $1-4$ people), crowded (5-7), and overcrowded (8 or more). Education level was classified into three categories (never went to school, primary school, and secondary school or higher education). Economic level was divided into two categories (poor, non-poor) according to a national poverty line, less than 150000 Vietnam dong (VND) (equivalent to 10 US dollars) or 150000 VND or more per capita average monthly income. ${ }^{8}$ Individual occupations were identified and categorised as occupations requiring boats, occupations not involving boats, or inactive.

\section{Sanitary practices}

Water treatment before drinking; washing of hands before eating; heating foods before eating; sources of water for cooking, drinking, bathing and washing; defecation sites; and garbage disposal sites.

\section{Disease prevention proficiency}

A "disease prevention proficiency score" was developed based on the subjects' knowledge regarding preventable diseases, knowledge of disease prevention practices, and practices preferable for disease prevention. Subjects were categorised into three groups based on the disease prevention proficiency score: non-functional (0 point), minimally functional (1-4 points), and functional (5-11 points).

\section{Preference to continued living on boats}

Subjects were asked whether they would prefer to continue living on boats, and their response was categorised as either affirmative or negative.

\section{Health examination}

Diseases and injuries in the past 12 months and currently were assessed by clinical medical doctors and coded according to the 10th version of International Statistical Classification Diseases and Related Health Problems (ICD10). ${ }^{9}$ A 12 month period was chosen to exclude the influence of variations in disease and injury prevalence relating to season. Four major disease categories (certain infectious and parasitic diseases, diseases of the respiratory system, diseases of the skin and subcutaneous tissue, and diseases of the digestive system) and injuries were recorded according to the disease prevalence records of Hue City. Selected specific diseases and injuries among major diseases and injuries were also recorded.

\section{Statistical analyses}

The distributions of age, education, and occupation of the subjects were calculated. The distributions of occupation by education and income level were analysed by $\chi^{2}$ test. The prevalence rates of the four major disease categories and injuries as well as selected specific diseases and injuries were quantified. Differences of the prevalence rates of major diseases and injuries by sex and age group children (5-14 years) compared with adults ( 15 years and over) and young adults (15-49) compared with older adults (50 years and over) were examined by $\chi^{2}$ test. The sex and age adjusted odds ratios (OR) and 95\% confident intervals (CI) of diseases and injuries for different family sizes, socioeconomic conditions, sanitary practices, and preference to continued living on boats were calculated by logistic regression analysis. ORs and $95 \%$ CIs of major diseases and injuries for increments of 1 in disease prevention proficiency score were calculated by logistic regression analysis. Three models were used: adjustment by sex and age; adjustment by sex, age, and occupation requiring/not requiring boats; and adjustment by sex, age, occupation requiring/not requiring boats, and education.

\section{RESULTS}

\section{Profiles of the subjects}

The results from 782 household visits were compiled for the analyses (83.1\% response rate). A total of 3737 subjects participated in the health examination $(73.8 \%$ of all reported family members aged 5 years and over). According to the reports made by the heads of the households, their households were made up of 2777 males and 2785 females with mean ages of 24.1 and 25.0 years, respectively. The median household size was seven people and $70.5 \%$ of the households were comprised of more than five people.

Table 1 shows age distribution, education, and occupation profiles of the subjects. Of the subjects aged 15 years and over, 39.2\% had never attended school, while 33.8\% had attended only primary school. Fishing, sand extraction, and transportation were the major occupations requiring boats, while vending, cyclo driver, and general labour were the major occupations that did not involve boats. "Poor" subjects made up $52.6 \%$ of the study population. The distribution of occupations requiring compared with those not requiring boats differed by education level; $49.7 \%$ of subjects who had participated in secondary school and above had occupations requiring boats, while $74.3 \%$ of those who had never attended school had such occupations $(p<0.001)$. There was also another difference according to income level; $81.6 \%$ of the "non-poor" and 57.6\% of "poor" subjects had occupations that required boats $(\mathrm{p}<0.01)$.

The percentages of households that used river water for cooking, drinking, bathing, and washing were $9.7 \%$, 10.7\%, $81.8 \%$, and $91.7 \%$, respectively. The percentages of households that reported they often or always boiled water before drinking, always washed their hands before eating and cooking, and always ensured foods were hot before eating were $42.6 \%, 26.3 \%$, and $72.7 \%$, respectively. The percentages of households that reported defecating directly into the river and throwing rubbish into the river were $85.4 \%$ and $54.0 \%$, respectively.

The mean and standard deviation of the disease prevention proficiency score of the 3607 subjects were 3.6 and 2.4, respectively, and the median value was 3 . The percentage distributions of the disease prevention proficiency by three categories-non-functional, minimally functional, and functional-were $3.1 \%, 64.2 \%$, and $32.7 \%$, respectively. 
Table 1 Basic profiles of the subjects living on boats

\begin{tabular}{|c|c|c|c|c|}
\hline \multirow[b]{2}{*}{ Characteristics } & \multicolumn{2}{|l|}{ Male } & \multicolumn{2}{|c|}{ Female } \\
\hline & $n$ & $\%$ & $n$ & $\%$ \\
\hline \multicolumn{5}{|l|}{ Age } \\
\hline $5-9$ & 321 & 17.5 & 331 & 17.4 \\
\hline $10-14$ & 348 & 18.9 & 337 & 17.7 \\
\hline $15-19$ & 215 & 11.7 & 184 & 9.7 \\
\hline $20-24$ & 124 & 6.8 & 141 & 7.4 \\
\hline $25-29$ & 133 & 7.2 & 137 & 7.2 \\
\hline $30-34$ & 146 & 7.9 & 141 & 7.4 \\
\hline $35-39$ & 106 & 5.8 & 119 & 6.3 \\
\hline $40-44$ & 97 & 5.3 & 123 & 6.5 \\
\hline $45-49$ & 95 & 5.2 & 127 & 6.7 \\
\hline $50-54$ & 73 & 4.0 & 78 & 4.1 \\
\hline $55-59$ & 36 & 2.0 & 41 & 2.2 \\
\hline Over 60 & 143 & 7.8 & 141 & 7.4 \\
\hline Total & 1837 & 100.0 & 1900 & 100.0 \\
\hline \multicolumn{5}{|l|}{ Education level* } \\
\hline Never gone to school & 366 & 31.3 & 575 & 46.7 \\
\hline Primary school & 474 & 40.6 & 337 & 27.4 \\
\hline Secondary school and above & 187 & 16.0 & 111 & 9.0 \\
\hline Data not available & 141 & 12.1 & 209 & 17.0 \\
\hline Total & 1168 & 100.0 & 1232 & 100.0 \\
\hline \multicolumn{5}{|l|}{ Major occupation* } \\
\hline \multicolumn{5}{|l|}{ Occupations requiring boats } \\
\hline Sand extraction & 447 & 38.3 & 398 & 32.3 \\
\hline Fishing & 192 & 16.4 & 103 & 8.4 \\
\hline Transportation & 34 & 2.9 & 30 & 2.4 \\
\hline Other occupations requiring boats & 39 & 3.3 & 67 & 5.4 \\
\hline \multicolumn{5}{|l|}{ Occupations not involving boats } \\
\hline Vending & 7 & 0.6 & 185 & 15.0 \\
\hline Cyclo driver & 172 & 14.7 & 2 & 0.2 \\
\hline Labour & 43 & 3.7 & 48 & 3.9 \\
\hline Other occupations not involving boats & 60 & 5.1 & 110 & 8.9 \\
\hline Inactive & 174 & 14.9 & 289 & 23.5 \\
\hline Total & 1168 & 100.0 & 1232 & 100.0 \\
\hline
\end{tabular}

Most subjects (95.1\%) reported that they would prefer not to continue living on boats, while the remaining subjects expressed no wish to change their living situation.

\section{Disease and injury patterns}

The prevalence rates of major diseases and injuries, both currently and over the past 12 months, among the subjects aged 5 years and over were $85.3 \%$ for certain infectious and parasitic diseases, $78.0 \%$ for diseases of the respiratory system, $51.2 \%$ for diseases of the skin and subcutaneous tissue, $15.4 \%$ for diseases of the digestive system, and $13.2 \%$ for injuries. Table 2 shows the prevalence rates of major diseases and injuries divided according to sex and age group. Injuries were more prevalent among males than among females $(p<0.001)$. Certain infectious and parasitic diseases, diseases of the respiratory system and diseases of the skin, and subcutaneous tissue were more prevalent among children than among adults $(\mathrm{p}<0.05, \mathrm{p}<0.001, \mathrm{p}<0.01$, respectively). Diseases of the skin and subcutaneous tissue, diseases of the digestive system and injuries were more

Table 2 Prevalence (\%) of major diseases and injuries in the past 12 months and currently among subjects by sex and age group

\begin{tabular}{|c|c|c|c|c|}
\hline & Male & Female & Children & Adults \\
\hline Major diseases/injuries (ICD-10 code) & $n=1837$ & $n=1900$ & $n=1337$ & $n=2400$ \\
\hline Certain infectious and parasitic diseases (A.00-B.99) & 86.2 & 84.5 & 87.2 & $84.3^{*}$ \\
\hline Diarrhoea and gastroenteritis of presumed infectious origin (A.09) & 67.6 & 67.2 & 70.4 & $65.7^{* *}$ \\
\hline Tuberculosis (A. 15-A.19) & 3.3 & 2.3 & 0.2 & $4.2^{* * *}$ \\
\hline Dengue fever/dengue haemorrhagic fever (A.90-A.91) & 7.1 & 5.7 & 7.2 & 6.0 \\
\hline Dermatophytosis (B.35) & 24.3 & $30.0^{* * *}$ & 11.7 & $35.8^{* * *}$ \\
\hline Malaria (B.50-B.54) & 15.4 & $6.1^{* * *}$ & 0.6 & $16.3^{* * *}$ \\
\hline Ascariasis (B.77) & 58.7 & 60.9 & 73.3 & $52.4^{* * *}$ \\
\hline Diseases of the respiratory system (J.00-J.99) & 77.9 & 78.0 & 82.7 & $75.3^{* * *}$ \\
\hline Asthma (J.45) & 3.8 & 3.1 & 4.6 & $2.8^{* *}$ \\
\hline Bronchitis and asthma (J.40-J.43, J.45) & 6.3 & $4.7^{*}$ & 8.4 & $3.8^{* * *}$ \\
\hline Diseases of the skin and subcutaneous tissue (L.OO-L.99) & 52.5 & 49.9 & 54.4 & $49.4^{* *}$ \\
\hline Dermatitis and eczema (L.20-L.30) & 12.8 & $10.7^{*}$ & 7.7 & $14.0^{* * *}$ \\
\hline Acne (L.70) & 7.7 & $5.5^{\star *}$ & 6.1 & 6.8 \\
\hline Diseases of the digestive system (K.00-K.93) & 16.4 & 14.5 & 1.8 & $23.0^{* * *}$ \\
\hline Injuries & 18.0 & $8.5^{\star \star \star}$ & 11.7 & 13.9 \\
\hline Injuries on boats & 7.0 & $5.2^{\star}$ & 5.3 & 6.5 \\
\hline Injuries on land & 9.5 & $3.1^{* \star *}$ & 6.5 & 6.1 \\
\hline Injuries at work & 1.4 & $0.3^{* * *}$ & - & - \\
\hline
\end{tabular}


Table 3 Adjusted odds ratios (OR) of major diseases and injuries in the past 12 months and currently by socioeconomic conditions among subjects living on boats

\begin{tabular}{|c|c|c|c|c|}
\hline \multirow[b]{2}{*}{ Major diseases/injuries (ICD-10 code) } & \multicolumn{2}{|c|}{$\begin{array}{l}\text { OR }(95 \% \mathrm{Cl}) \text { in reference to subjects who completed } \\
\text { secondary school }(n=298) \text {, subjects } 15 \text { years and } \\
\text { over }\end{array}$} & \multirow{2}{*}{$\begin{array}{l}\text { OR }(95 \% \mathrm{Cl}) \text { in reference to } \\
\text { subjects with occupations } \\
\text { not involving boats } \\
\text { ( } \mathrm{n}=620) \text {, subjects } 15 \text { years } \\
\text { and over } \\
\begin{array}{l}\text { Occupation requiring boats } \\
\text { ( } \mathrm{n}=1303 \text { ) }\end{array}\end{array}$} & \multirow{2}{*}{$\begin{array}{l}\text { OR }(95 \% \mathrm{Cl}) \text { in reference to } \\
\text { non-poort subjects } \\
(n=1418) \text {, subjects } 5 \text { years } \\
\text { and over } \\
\text { Poor }(n=2319)\end{array}$} \\
\hline & $\begin{array}{l}\text { Primary school } \\
(n=811)\end{array}$ & $\begin{array}{l}\text { Never went to } \\
\text { school }(\mathbf{n}=941)\end{array}$ & & \\
\hline Certain infectious and parasitic diseases (A.00-B.99) & $1.43(1.00 \text { to } 2.03)^{*}$ & $1.31(0.90$ to 1.90$)$ & $1.13(0.87$ to 1.47$)$ & $1.12(0.93$ to 1.34$)$ \\
\hline $\begin{array}{l}\text { Diarrhoea and gastroenteritis of presumed infectious } \\
\text { origin (A.09) }\end{array}$ & $1.27(0.96$ to 1.68$)$ & $1.38(1.03 \text { to } 1.87)^{*}$ & $0.99(0.81$ to 1.21$)$ & $1.05(0.91$ to 1.21$)$ \\
\hline Tuberculosis (A.15-A.19) & $0.90(0.40$ to 2.04$)$ & 1.05 (0.46 to 2.42$)$ & $0.46(0.28 \text { to } 0.74)^{\star *}$ & $1.62(1.03 \text { to } 2.53)^{*}$ \\
\hline $\begin{array}{l}\text { Dengue fever/dengue haemorrhagic fever } \\
\text { (A.90-A.91) }\end{array}$ & $0.69(0.42$ to 1.13$)$ & 0.62 (0.36 to 1.07$)$ & $1.08(0.72$ to 1.63$)$ & $0.71(0.55 \text { to } 0.93)^{*}$ \\
\hline Dermatophyłosis (B.35) & $1.95(1.42 \text { to } 2.69)^{* * *}$ & $2.44(1.75 \text { to } 3.41)^{\star \star *}$ & $1.52(1.24 \text { to } 1.86)^{\star \star *}$ & $0.81(0.69 \text { to } 0.93)^{\star \star}$ \\
\hline Malaria (B.50-B.54) & $2.14(1.37 \text { to } 3.33)^{\star * *}$ & $2.17(1.36 \text { to } 3.45)^{\star *}$ & 1.31 (0.99 to 1.72$)$ & $0.88(0.70$ to 1.10$)$ \\
\hline Ascariasis (B.77) & $1.25(0.96$ to 1.65$)$ & $1.49(1.12 \text { to } 1.99)^{* *}$ & $1.12(0.92$ to 1.36$)$ & $1.01(0.88$ to 1.16$)$ \\
\hline Diseases of the respiratory system (J.00-J.99) & $1.34(0.99$ to 1.82$)$ & $1.63(1.18 \text { to } 2.26)^{* *}$ & $1.07(0.85$ to 1.34$)$ & $0.96(0.82$ to 1.13$)$ \\
\hline Asthma (J.45) & $1.76(0.71$ to 4.38$)$ & $1.53(0.58$ to 4.05$)$ & $1.12(0.62$ to 2.03$)$ & $0.76(0.53$ to 1.09$)$ \\
\hline Bronchitis and asthma (J.40-J.43, J.45) & $1.92(0.87$ to 4.20$)$ & $1.51(0.65$ to 3.50$)$ & 1.05 (0.63 to 1.73$)$ & $0.86(0.64$ to 1.15$)$ \\
\hline Diseases of the skin and subcutaneous tissue (L.00-L.99) & $1.38(1.05 \text { to } 1.81)^{*}$ & $1.74(1.30 \text { to } 2.33)^{\star \star \star}$ & $1.10(0.91$ to 1.33$)$ & $1.18(1.04 \text { to } 1.35)^{*}$ \\
\hline Dermatitis and eczema (L.20-L.30) & $0.98(0.64$ to 1.52$)$ & $1.29(0.83$ to 2.01$)$ & $1.42(1.06 \text { to } 1.90)^{*}$ & $0.80(0.65 \text { to } 0.98)^{*}$ \\
\hline Acne (L.70) & $1.25(0.74$ to 2.10$)$ & $1.28(0.74$ to 2.24$)$ & $0.74(0.51$ to 1.06$)$ & $1.17(0.89$ to 1.53$)$ \\
\hline Diseases of the digestive system (K.00-K.93) & $1.98(1.32 \text { to } 2.97)^{\star \star \star}$ & $2.24(1.48 \text { to } 3.40)^{\star \star *}$ & $0.94(0.75$ to 1.18$)$ & $0.91(0.75$ to 1.10$)$ \\
\hline Injuries & $0.58(0.41 \text { to } 0.84)^{\star *}$ & $0.60(0.41 \text { to } 0.89)^{*}$ & $0.75(0.56 \text { to } 0.99)^{*}$ & $1.11(0.91$ to 1.35$)$ \\
\hline Injuries on boats & $0.99(0.53$ to 1.56$)$ & $0.82(0.46$ to 1.47$)$ & $1.34(0.88$ to 2.05$)$ & $0.81(0.62$ to 1.06$)$ \\
\hline Injuries on land & $0.40(0.24 \text { to } 0.65)^{\star \star *}$ & $0.44(0.26 \text { to } 0.75)^{\star \star}$ & $0.44(0.29 \text { to } 0.66)^{\star * *}$ & $1.62(1.20 \text { to } 2.18)^{\star \star}$ \\
\hline Injuries at work & $1.23(0.38$ to 3.93$)$ & $1.62(0.48$ to 5.46$)$ & $0.80(0.35$ to 1.81$)$ & $0.74(0.36$ to 1.51$)$ \\
\hline
\end{tabular}

prevalent among older adults than among young adults (53.7\% v 48.3\%, $\mathrm{p}<0.05 ; 32.0 \% \vee 20.6 \%, \mathrm{p}<0.001 ; 19.3 \% \vee$ $12.4 \%, \mathrm{p}<0.001$, respectively).

Table 3 shows the adjusted odds ratios of major diseases and injuries by education, occupation, and income. Diseases of the respiratory system, diseases of the skin and subcutaneous tissue, and diseases of the digestive system were more prevalent among subjects who had never gone to school than among those who had attended secondary school and above $(\mathrm{p}<0.01, \mathrm{p}<0.001, \mathrm{p}<0.001$, respectively $)$, while the inverse association was found for injuries $(p<0.05)$. Regarding the relation between injuries and occupations, injuries were more prevalent among subjects with occupations not requiring boats than among those with occupation requiring boats $(\mathrm{p}<0.05)$. Regarding the associations between major diseases and income, the diseases of the skin and subcutaneous tissue were more prevalent among "poor" subjects than among "non-poor" subjects $(\mathrm{p}<0.05)$. Diseases of skin and subcutaneous tissue among "overcrowded" households was more prevalent than that among "non-crowded" households $(52.3 \% \quad v 46.0 \%, \mathrm{p}<0.01)$. Injuries among "overcrowded" households was more prevalent than that among "non-crowded" households, ( $13.4 \% \mathrm{v}$ $10.4 \%, \mathrm{p}<0.05$ ).

Table 4 shows the adjusted odds ratios for major diseases and injuries by sanitary practices. Certain infectious and

Table 4 Adjusted odds ratios (OR) for major diseases and injuries in the past 12 months and currently by sanitary practices among subjects aged 5 years and over living on boats

\begin{tabular}{|c|c|c|c|c|c|}
\hline Major diseases/injuries & $\begin{array}{l}\text { Certain infectious and } \\
\text { parasitic diseases }\end{array}$ & $\begin{array}{l}\text { Diseases of the } \\
\text { respiratory system }\end{array}$ & $\begin{array}{l}\text { Diseases of the skin and } \\
\text { subcutaneous tissue }\end{array}$ & $\begin{array}{l}\text { Diseases of the digestive } \\
\text { system }\end{array}$ & \\
\hline (ICD-10 code) & (A.00-B.99) & (J.00-J.99) & (L.00-L.99) & (K.00-K.93) & Injuries \\
\hline \multicolumn{6}{|c|}{ Water treatment before drinking } \\
\hline Often or always boil $(n=1539)$ & 1.00 & 1.00 & 1.00 & 1.00 & 1.00 \\
\hline Sometimes boil $(n=1709)$ & $1.37(1.14 \text { to } 1.65)^{\star \star *}$ & $1.07(0.91$ to 1.25$)$ & $1.13(0.98$ to 1.29$)$ & 1.09 (0.88 to 1.35$)$ & 0.91 (0.74 to 1.13$)$ \\
\hline Never boil $(n=479)$ & $4.70(3.01 \text { to } 7.34)^{* \star *}$ & $5.14(3.47 \text { to } 7.62)^{* * *}$ & $4.49(3.53 \text { to } 5.72)^{\star \star *}$ & $2.85(2.18 \text { to } 3.73)^{* \star *}$ & $1.67(1.27 \text { to } 2.21)^{* * *}$ \\
\hline \multicolumn{6}{|l|}{ Wash hands before eating } \\
\hline Always $(n=899)$ & 1.00 & 1.00 & 1.00 & 1.00 & 1.00 \\
\hline Often $(n=2216)$ & $1.52(1.24 \text { to } 1.86)^{\star \star *}$ & $1.09(0.91$ to 1.31$)$ & $1.19(1.02 \text { to } 1.39)^{*}$ & 0.93 (0.73 to 1.18 ) & $0.61(0.49 \text { to } 0.77)^{* * *}$ \\
\hline No $(n=569)$ & $3.99(2.73 \text { to } 5.82)^{\star \star \star}$ & $3.15(2.30 \text { to } 4.30)^{\star \star *}$ & $4.01(3.18 \text { to } 5.06)^{\star \star \star}$ & $2.20(1.66 \text { to } 2.93)^{* \star *}$ & $1.20(0.91$ to 1.59$)$ \\
\hline \multicolumn{6}{|l|}{$\begin{array}{l}\text { Ensure foods are hot before } \\
\text { eating }\end{array}$} \\
\hline Always ( $n=2665$ ) & 1.00 & 1.00 & 1.00 & 1.00 & 1.00 \\
\hline Sometimes $(n=538)$ & $5.32(3.46 \text { to } 8.17)^{\star * *}$ & $6.58(4.55 \text { to } 9.50)^{* \star *}$ & $3.13(2.57 \text { to } 3.82)^{* * *}$ & $0.46(0.33 \text { to } 0.65)^{* * *}$ & 0.99 (0.74 to 1.32$)$ \\
\hline No $(n=481)$ & $15.92(7.52 \text { to } 33.70)^{* * *}$ & $13.76(8.03 \text { to } 23.58)^{* * *}$ & $10.38(7.82 \text { to } 13.77)^{\star * *}$ & $2.94(2.31 \text { to } 3.73)^{* * *}$ & $1.89(1.46 \text { to } 2.44)^{* * \star}$ \\
\hline \multicolumn{6}{|l|}{ Sources of water for washing } \\
\hline Either tap or river $(n=656)$ & 1.00 & 1.00 & 1.00 & 1.00 & 1.00 \\
\hline Always from river $(n=3038)$ & $1.66(1.33 \text { to } 2.06)^{* * *}$ & $1.48(1.22 \text { to } 1.79)^{* * *}$ & $1.77(1.49 \text { to } 2.10)^{* * *}$ & $1.22(0.95$ to 1.57$)$ & $1.10(0.85$ to 1.43$)$ \\
\hline \multicolumn{6}{|l|}{ Sources of water for bathing } \\
\hline Either tap or river $(n=599)$ & 1.00 & 1.00 & 1.00 & 1.00 & 1.00 \\
\hline Always river $(n=2532)$ & $2.38(1.91 \text { to } 2.97)^{* * *}$ & $1.26(1.02 \text { to } 1.55)^{*}$ & $1.95(1.62 \text { to } 2.33)^{* * *}$ & $1.68(1.26 \text { to } 2.23)^{\star * *}$ & 1.01 (0.77 to 1.31$)$ \\
\hline
\end{tabular}


Table 5 Prevalence and adjusted odds ratios (OR) of major diseases and injuries in the past 12 months and currently among subjects 5 years and over living on boats according to disease prevention proficiency $\dagger$

\begin{tabular}{|c|c|c|c|c|c|c|}
\hline \multirow[b]{3}{*}{ Major diseases/injuries (ICD-10 code) } & \multicolumn{3}{|c|}{$\begin{array}{l}\text { Prevalence (\%) by category of disease } \\
\text { prevention proficiency }\end{array}$} & \multirow[b]{3}{*}{ OR $(95 \% \mathrm{Cl}) \pm$} & \multirow[b]{3}{*}{ OR $(95 \% \mathrm{Cl}) \S$} & \multirow[b]{3}{*}{ OR $(95 \% \mathrm{Cl})$ q } \\
\hline & Non-functional & $\begin{array}{l}\text { Minimally } \\
\text { functional }\end{array}$ & Functional & & & \\
\hline & $(n=112)$ & $(n=2317)$ & $(n=1178)$ & & & \\
\hline $\begin{array}{l}\text { Certain infectious and parasitic diseases } \\
\text { (A.00-B.99) }\end{array}$ & 98.2 & 85.5 & 83.8 & $0.76(0.64 \text { to } 0.91)^{* *}$ & $0.74(0.58 \text { to } 0.94)^{*}$ & $0.72(0.56 \text { to } 0.94)^{*}$ \\
\hline $\begin{array}{l}\text { Diarrhoea and gastroenteritis of presumed } \\
\text { infectious origin (A.09) }\end{array}$ & 75.9 & 68.8 & 63.3 & $0.77(0.67 \text { to } 0.88)^{\star \star *}$ & $0.73(0.61 \text { to } 0.87)^{\star \star \star}$ & $0.72(0.59 \text { to } 0.87)^{* \star *}$ \\
\hline Tuberculosis (A.15-A.19) & 1.8 & 2.5 & 3.1 & $1.50(1.01 \text { to } 2.24)^{*}$ & $1.28(0.78$ to 2.09$)$ & $1.34(0.79$ to 2.28$)$ \\
\hline $\begin{array}{l}\text { Dengue fever/dengue haemorrhagic fever } \\
\text { (A.90-A.91) }\end{array}$ & 1.8 & 6.9 & 5.3 & $0.88(0.67$ to 1.14$)$ & $0.79(0.55$ to 1.13$)$ & $0.70(0.47$ to 1.04$)$ \\
\hline Dermatophyłosis (B.35) & 33.9 & 30.3 & 20.4 & $0.64(0.56 \text { to } 0.75)^{\star \star \star}$ & $0.69(0.57 \text { to } 0.83)^{\star \star \star}$ & $0.67(0.55 \text { to } 0.82)^{\star \star \star}$ \\
\hline Malaria (B.50-B.54) & 8.9 & 11.0 & 10.2 & $1.04(0.84$ to 1.30$)$ & $1.12(0.88$ to 1.42$)$ & $1.10(0.85$ to 1.42$)$ \\
\hline Ascariasis (B.77) & 84.8 & 58.9 & 60.4 & $0.87(0.76 \text { to } 0.99)^{*}$ & $0.84(0.70 \text { to } 1.00)^{*}$ & $0.77(0.63 \text { to } 0.93)^{* *}$ \\
\hline Diseases of the respiratory system (J.00-J.99) & 93.8 & 78.8 & 74.5 & $0.70(0.60 \text { to } 0.82)^{* * *}$ & $0.61(0.50 \text { to } 0.75)^{* * *}$ & $0.57(0.46 \text { to } 0.71)^{* * *}$ \\
\hline Asthma (J.45) & 0.9 & 3.4 & 3.4 & $1.10(0.78$ to 1.56$)$ & 1.11 (0.67 to 1.83$)$ & $1.09(0.63$ to 1.87$)$ \\
\hline Bronchitis and asthma (J.40-J.43, J.45) & 1.8 & 5.6 & 5.1 & $0.99(0.75$ to 1.31$)$ & 1.01 (0.65 to 1.56$)$ & $0.97(0.61$ to 1.54$)$ \\
\hline $\begin{array}{l}\text { Diseases of the skin and subcutaneous tissue } \\
\text { (L.00-L.99) }\end{array}$ & 72.3 & 53.0 & 44.2 & $0.65(0.58 \text { to } 0.74)^{* \star *}$ & $0.63(0.53 \text { to } 0.75)^{\star * *}$ & $0.59(0.49 \text { to } 0.72)^{* \star *}$ \\
\hline Dermatitis and eczema (L.20-L.30) & 17.9 & 13.3 & 6.8 & $0.54(0.44 \text { to } 0.67)^{* * *}$ & $0.53(0.40 \text { to } 0.69)^{* * *}$ & $0.52(0.39 \text { to } 0.69)^{\star \star \star}$ \\
\hline Acne (L.70) & 7.1 & 5.7 & 7.7 & $1.26(0.98$ to 1.63$)$ & $1.12(0.79$ to 1.57$)$ & $0.97(0.67$ to 1.40$)$ \\
\hline Diseases of the digestive system (K.00-K.93) & 14.3 & 15.8 & 15.0 & $1.06(0.88$ to 1.28$)$ & $1.07(0.87$ to 1.33$)$ & $1.08(0.86$ to 1.36$)$ \\
\hline Injuries & 8.9 & 12.4 & 14.8 & $1.26(1.04 \text { to } 1.52)^{*}$ & $1.20(0.92$ to 1.55$)$ & $1.20(0.91$ to 1.58$)$ \\
\hline Injuries on boats & 5.4 & 6.3 & 5.5 & $0.92(0.70$ to 1.20$)$ & $0.92(0.63$ to 1.32$)$ & $0.90(0.60$ to 1.33$)$ \\
\hline Injuries on land & 2.7 & 5.5 & 8.0 & $1.55(1.20 \text { to } 2.01)^{* * *}$ & $1.43(0.97$ to 2.09$)$ & $1.45(0.97$ to 2.15$)$ \\
\hline
\end{tabular}

${ }^{*} p<0.05 ;{ }^{* *} p<0.01 ;{ }^{* \star *} p<0.001$. Individual assessment items included the names of selected infectious and parasitic diseases, measures to prevent infectious and parasitic diseases, measures to prevent malnutrition, sanitary practices, and participation in health education programmes. prevention proficiency and $95 \%$ confidence interval $(95 \% \mathrm{Cl}$ ), adjusted by sex and age. $\S$ Odds ratio (OR) for an increment of 1 in score of disease prevention proficiency and $95 \%$ confidence interval $(95 \% \mathrm{Cl})$, adjusted by sex, age, and occupation requiring/not requiring boats. ๆ Odds ratio (OR) for an increment of 1 in score of disease prevention proficiency and $95 \%$ confidence interval $(95 \% \mathrm{CI})$, adjusted by sex, age, occupation requiring/not requiring boats, and education.

parasitic diseases, diseases of the respiratory system, diseases of the skin and subcutaneous tissue, and diseases of the digestive system showed significantly high prevalence rates among subjects who had improper sanitary practices such as never boiled water before drinking, never wash hands before eating, never ensure foods were hot before eating, and use river water for washing or bathing.

Table 5 shows the prevalence of major diseases and injuries divided according to disease prevention proficiency. ORs and $\mathrm{p}$ values calculated for three models with different combinations of adjustment variables were generally consistent except the results for injuries on land. Higher disease prevention proficiency was significantly related to lower prevalence of certain infectious and parasitic diseases $(p<0.05)$, diseases of the respiratory system $(p<0.001)$, and diseases of the skin and subcutaneous tissue $(p<0.001)$, after adjustment by sex, age, occupation, and education.

People who preferred not to continue living on boats were more likely to have higher prevalence rates of certain infectious and parasitic diseases $(p<0.01)$, diseases of the respiratory system $(\mathrm{p}<0.001)$, and diseases of the skin and

\section{What this paper adds}

People living on boats are underprivileged with regard both to socioeconomic and living conditions. However, there have been no previous quantitative studies of disease patterns in such populations. This comprehensive field study performed in Hue City, Vietnam, illustrated the major diseases and injuries occurring among people living on boats and showed a web-like relation between health status, socioeconomic conditions, sanitary practices, disease prevention proficiency, and preference to continued living on boats. subcutaneous tissue $(\mathrm{p}<0.01)$ than those who expressed no wish to change their living situation.

\section{DISCUSSION}

The results of this quantitative study showed the prevalence of certain infectious and parasitic diseases, diseases of the respiratory system, diseases of the skin and subcutaneous tissue, diseases of the digestive system, and injuries among people living on boats in Hue City. The prevalence rates of the diseases and injuries were significantly associated with sanitary practices, disease prevention proficiency, and subjects' preference regarding continued living on boats. Disease prevention proficiency was shown to be conducive to reducing the prevalence rates of certain infectious and parasitic diseases, diseases of the respiratory system, and diseases of the skin and subcutaneous tissue regardless of the subjects' sex, age, or socioeconomic status.

In Vietnam, efforts have been made to provide people with access to primary health care services within five kilometres from their home. ${ }^{10}$ However, families living under fragile

\section{Policy implications}

- Our findings regarding variations in health status among people living on boats provide a basis for the development of measures to improve the health of populations living under specific fragile conditions.

- Resettlement of people living on boats onto the land and programmes to improve disease prevention proficiency by taking account of the peoples' experience, in addition to secure means of income, will benefit health development in this population under fragile conditions. 
conditions have been reported to have fewer visits to health care facilities than those higher on the socioeconomic scale. ${ }^{11}$ Therefore, disease statistics reported from health care facilities generally do not accurately reflect health situations of people living under fragile conditions. In this study, a response rate of $83.1 \%$ was achieved from a population living under fragile conditions. In the study area, along the Huong River, there is a long history of households living on boats. Almost all households living on boats in the area are on the household registration records. Therefore, this study was regarded as providing comprehensive quantitative data of the prevalence rates of disease and injury among people aged 5 years and over living on boats in Hue City. The report of the health status of children less than 5 years old in the study area, available from Hue-Bretagne boat clinic, will complement information regarding disease and injury patterns in the population as a whole. The participation of local medical doctors visiting boat households for onsite health examinations encouraged families to participate in the survey. The participation and cooperation of the heads of quarters in the preparation and implementation of the survey facilitated people's understanding of the survey activities. This process also contributed to improvement of security during the survey in the study area. Although most health problems were well diagnosed by local medical doctors, diagnosis of mental health problems, and diseases related to reproduction were regarded as unsuitable for a general community health survey; therefore, these diagnoses were excluded from this study. Future studies focusing specifically on these problems will widen our understanding of the disease and injury patterns of this population.

The prevalence rates of selected infectious and parasitic diseases were comparatively high in the study population. The prevalence of tuberculosis per 100000 people was 580 per year, which was fivefold greater than the national estimate of $119^{12}$ and fourfold greater than the areal estimate of $140 .^{13}$ The proportion of poor people among the study population, $52.6 \%$, was considerably higher than the national average, $17.2 \%{ }^{8}$ Poverty was considered to be among the factors responsible for the high prevalence of tuberculosis in this population.

The prevalence of ascariasis was 1.4-fold higher than the national estimate, $44.4 \% .{ }^{14}$ Low communal services for people living in river villages are related to the high prevalence of ascariasis. ${ }^{15}$ The number of reported cases of malaria $(10.3 \%$ per year) was higher than those in seven other regions in Vietnam (range, $0.3 \%-4.7 \%$ per year reported in 1998), ${ }^{16}$ although the incidence and prevalence of malaria have been reduced significantly in Vietnam because of malaria control efforts. ${ }^{17}$ The prevalence rate of dengue fever/dengue haemorrhagic fever (6.4\% per year) was 10 -fold higher than that reported in another region of Vietnam $\left(0.44 \%\right.$ per year). ${ }^{18}$ These differences were probably related to the increased frequency of exposure to mosquito breeding sites of those living on the Huong River and its branches. ${ }^{19}$

The prevalence rates of diseases of the respiratory system and diseases of the skin and subcutaneous tissue were comparatively high (sixfold and fivefold greater, respectively) as compared with those in the communities on land along the river in Hue. ${ }^{20}$

The relations among education, occupation requiring/not requiring boats, income, and risks of disease and injury are complex in people living under fragile conditions. Statistical adjustment by sex and age group is useful in the analysis of these relations among people living on boats, because of the significant differences in the prevalence of diseases and injuries by sex and age group. The subjects in this study showed reduced rates of participation in school education, indicating that they had low education levels. Lack of opportunities for school education have also been reported in some countries belonging to the Association of Southeast Asia Nations (ASEAN) where adult illiteracy rates were reported to range from $2.8 \%$ to $35.9 \%$ for men and $4.8 \%$ to $66.8 \%$ for women in $2000 .{ }^{21}$ Lower educational attainment was related to a higher risk of major diseases but lower risk of injury. The first relation has been seen in other low income countries. $^{22}{ }^{23}$ The second relation-the association between lower educational level and lower risk of injury-was because people with lower educational level were more likely to work on boats where the risk of injuries was considered to be comparatively small. In contrast, work on land such as cyclo driver, labour, and vending, is regarded as a risk of injuries in crowded urban spaces.

The prevalence rates of dermatophytosis, and dermatitis and eczema were high among non-poor subjects, most of whom had occupations involving boats. Occupations requiring boats, such as sand extraction, fishing, and transportation, brought higher incomes than occupations that do not involve boats. At the same time, occupations requiring boats reflect working environments, on the Huong River and its branches, exposure to river water contaminated with faeces and waste. ${ }^{10}$ These working environments are regarded as risks to the particular infectious and skin diseases mentioned above.

In contrast, tuberculosis was more prevalent among poor subjects than non-poor subjects. Poverty among tuberculosis patients may be explained as a background risk factor but also as a consequence of this long term illness that restricts patients' income generating activities and thus results in isolation from social activities. ${ }^{24-26}$ Most poor subjects were involved in occupation not requiring boats, such as cyclo driver, labour, and vending. These occupations were regarded as a risk of tuberculosis because they are associated with contacts with unspecified large number of people in urban crowded spaces.

People living on boats along the Huong River struggled with their means of income, working environments, and risk of diseases. To earn slightly better incomes, people chose occupations involving boats where the risks of particular diseases are high because of the river environment. People with slightly higher educational levels chose occupations on land and had higher risks of injury and tuberculosis but comparatively lower risks of some other infectious diseases.

People living on boats used the Huong River for defecation and rubbish disposal as well as a source of water for drinking, cooking, washing, and bathing thus leading to high risks of skin diseases and diseases transmitted orofecally. Associations between personal hygiene and both ascariasis and diarrhoeal disease have been reported previously. ${ }^{22} 28$ Sanitary practices were also critically related to other major diseases, as reported in other low income communities. ${ }^{26}{ }^{29}$

Functional disease prevention proficiency lowered the prevalence of a wide range of diseases, and this association was found even after excluding the influence of occupations requiring/not requiring boats and subjects' educational level. Improvements in health literacy in low income countries can be achieved by community based programmes to meet the needs of the communities. ${ }^{30}$ Almost all communities in Vietnam have their own health stations. They deliver public health information, expanding health education and curative care. ${ }^{10}$ These health stations could be a focal point in programmes to improve disease prevention proficiency. The recent development of programmes in Hue City to increase disease prevention proficiency will contribute to decrease the risk of disease.

Fragile living conditions on boats may encourage more people to consider adopting a life on land, despite the uncertainty regarding the security of the means of income of 
occupations requiring boats or those on land. Relocation from living on boats to settlement on land would improve sanitary conditions. Based on census data, we estimated that $2 \%$ of urban population in Vietnam live under fragile conditions along rivers or canals. ${ }^{4}{ }^{31}$ Improvement of disease prevention proficiency of the urban boat population through appropriate interventions taking account of the person's experience must be considered in addition to a secure means of income when they begin living on land.

In conclusion, this large scale comprehensive field study in Hue City, Vietnam, quantified major diseases and injuries among people living on boats to provide solid evidence on which to base policy making decisions. Variations in health status in this population showed a complex relation with education, occupations requiring/not requiring boats, income, sanitary practices, disease prevention proficiency, and people's preference to continued living on boats. Programmes to improve disease prevention proficiency that take into account both way of life and occupation would reduce the risk of disease and injury in this fragile urban population.

\section{ACKNOWLEDGEMENTS}

We acknowledge members of the Hue People's Committee, Mr Nguyen Viet Tien, former mayor and Mr Nguyen Van Cao, present mayor; Dr Nguyen Nhien, Director of the Bureau of Foreign Affairs of Hue City; Dr Tran Bui, Director of the Hue Healthcare Center for supporting this study. We thank the local leaders of the six quarters, the medical doctors of the Hue Healthcare Center, the chiefs of the six health stations, and all of the government staff of the Bureau of Foreign Affairs of Hue City for their contribution to implementation of these field works.

\section{Authors' affiliations}

N K L Quang, T Takano, M Watanabe, T Inose, Y Fukuda, Health Promotion, Department of International Health Development, Graduate School of Tokyo Medical and Dental University, Tokyo, Japan K Nakamura, K Seino, International Health and Medicine, Department of International Health Development, Graduate School of Tokyo Medical and Dental University

Funding: this study was partly supported by Grants-in-Aid for Scientific Study by Japan Society for Promotion of Science.

Conflicts of interests: none.

\section{REFERENCES}

1 United Nations. World urbanization prospects, the 2003 revision. New York: United Nations, 2003

2 Nhien N. Community participation and urban policies on health and environment of the city of Hue: Vietnam. In: Takano T, ed. Healthy cities and urban policy research. London: Spon Press, 2003:261-4.

3 Bui T. Report on Healthy City Programme of Hue City. Workshop on healthy cities: preparing for the 21 st century, WPR/EUD/EHE (O) (2)/99/INF, /14, Manila, Western Pacific Region, 1999: 1-4.

4 Hue Government. The project of residing people living on boat in Hue city Hue City: Hue Government, 2002.
5 World Health Organisation. Ottawa Charter for Health Promotion. Health Promot 1986; 1:iii-v.

6 Takano T, Nakamura K. An analysis of health levels and various indicators of urban environments for Healthy Cities projects. J Epidemiol Community Health 2001:55:263-70.

7 World Health Organisation. Quantifying selected major risks to health. In: World health report 2002. Geneva: WHO, 2002:47-97.

8 Vietnam. The comprehensive poverty reduction and growth strategy, No. 2685/VPCP-QHQT. Hanoi: Vietnam, 2002.

9 World Health Organisation. International statistical classification of diseases and related health problems, tenth version. Geneva: WHO, 1992.

10 Committee for Population, Family and Children Vietnam. Vietnam demographic and health survey 2002. Hanoi: General Statistical Office of Vietnam, 2003.

11 Falkingham J. Poverty, out-of-pocket payments and access to health care: evidence from Tajikistan. Soc Sci Med 2004;58:247-58.

12 World Health Organisation. Vietnam country profile. Global tuberculosis control: surveillance, planning, financing. Geneva: WHO, 2004:120-2.

13 Hue Health Care Center. Hue health report 2004. Hue City: Hue Health Care Center, 2004

14 van der Hoek W, De NV, Konradsen F, et al. Current status of soil-transmitted helminthes in Vietnam. Southeast Asian J Trop Med Public Health 2003:34:1-11.

15 Curtale F, Pezzotti P, Saad YS, et al. An analysis of individual, household, and environmental risk factors for intestinal helminth infection among children in Qena Governorate, upper Egypt. J Trop Pediatr 1999;45:14-17.

16 Laxminarayan R. Dose reducing malaria improve household living standards? Trop Med Int Health 2004:9:267-72.

17 Nam NV, de Vries PJ, Toi LV, et al. Malaria control in Vietnam: the Binh Thuan experience. Trop Med Int Health 2005; 10:357-65.

18 Do QH, Nguyen TKT, Vu TQH, et al. Dengue epidemic in Southern Vietnam, 1998. Emerg Infect Dis 2000;6:422-5.

19 Birley MH. Guidelines for the forecasting of vector-borne disease implications of water resources development. WHO/CWS/91.3. Geneva: WHO, 1991.

20 Hau TD. ACWP mobile healthcare program, 2003 report. Hue City: Hue Medical College, 2003

21 Lee ISM. Baseline data in ASEAN member countries. In: Takano T, ed. Healthy cities and urban policy research. London: Spon Press, 2003:190-221.

22 Holland CV, Taren DL, Crompton DWT, et al. Intestinal helminthiasis in relation to the socioeconomic environment of Panamanian children. Soc Sci Med 1988;26:209-13.

23 Traub RJ, Robertson ID, Irwin P, et al. The prevalence, intensities and risk factors associated with geohelminth infection in tea-growing communities of Assam, India. Trop Med Int Health 2004;9:688-701.

24 World Resources Institute. Changing environments, changing health. In: World resources 1998-1999: a guide to the global environment: environment change and human health. Washington, DC: World Resources Institute, 1998:36-72.

25 Long NH, Johansson E, Diwan VK, et al. Fear and social isolation as consequences of tuberculosis in Vietnam: a gender analysis. Health Policy 2001;58:69-81.

26 Gustafson P, Gomes VF, Vieira CS, et al. Tuberculosis in Bissau: incidence and risk factors in an urban community in sub-Saharan Africa. Int J Epidemiol 2004;33: 163-72.

27 Atukorala TMS, Lanerolle P. Soil transmitted helminthic infection and its effect on nutritional status of adolescent schoolgirls of low socioeconomic status in Sri Lanka. J Trop Pediatr 1999;45:18-22.

28 Tumwine JK, Thompson J, Katua-Katua $M$, et al. Diarrhea and effects of different water sources, sanitation and hygiene behaviour in East Africa. Trop Med Int Health 2002;7:750-6.

29 Dogra S, Kumar B. Epidemiology of skin diseases in school children: a study from northern India. Pediatr Dermatol 2003;20:470-3.

30 Ohnishi M, Nakamura K, Takano T. Improvement in maternal health literacy among pregnant women who did not complete compulsory education: policy implications for community care services. Health Policy 2004;72:157-64

31 Bolay JC, Cartoux S, Cunha A, et al. Sustainable development and urban growth: precarious habitat and water management in Ho Chi Minh City, Vietnam. Habitat Int 1997;21:185-97. 